TERAKREDITASI Berdasarkan SK Dirjen Dikti Depdiknas Nomor: 65a/DIKTl/Kep/2008

MENIMBANG KOMPATIBELITAS MULTIKULTURALISME DAN ISLAM: IKHTIAR MENGGAGAS PENDIDIKAN ISLAM MULTIKULTURAL DI INDONESIA Mukhlis

ASESMEN AKHLAK MULIA: Suatu Model Alternatif Penilaian Pembelajaran Agama Siti Muri'ah

MENILAI Ulang GAGASAN NEGARA KHILÂFAH ABÛ AL-A'LÂ AL-MAUDÛDî Arsyad Sobby Kesuma

AL-A'IMMAH MIN QURAISY: ANTARA DOKTRIN DAN KEBUTUHAN SOSIAL Ahwan Mukarrom

SISTEM KALENDER ISLAM DALAM PERSPEKTIF EVOLUSI SYARI'AA Abd. Salam

Desain DakWAH untuk PEMBINAan KeAgamaAn KOMUNITAS ELIT INTELEKTUAL Bukhari 


\section{PEDOMAN TRANSLITERASI}

\begin{tabular}{|c|c|c|c|}
\hline Arab & Latin & Arab & Latin \\
\hline 1 & $=$ & ف & $=\mathbf{f}$ \\
\hline ب & $=$ & ق & $=\mathrm{q}$ \\
\hline$\dot{H}$ & ts & ك & $=\mathrm{k}$ \\
\hline 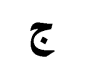 & $=$ & J & $=1$ \\
\hline$\tau$ & $=$ & r & $=\mathrm{m}$ \\
\hline$\dot{\tau}$ & $=\mathbf{k h}$ & ن & $=\mathbf{n}$ \\
\hline$د$ & $=$ & و & $=\mathbf{w}$ \\
\hline$\dot{j}$ & $\mathrm{dz}$ & ○ & $=h$ \\
\hline J & $=$ & $\varepsilon$ & $=$, \\
\hline j & $=$ & ي & $=\mathbf{y}$ \\
\hline س & $=$ & & \\
\hline ص ش & $\begin{array}{l}\text { sy } \\
\text { sh }\end{array}$ & \multicolumn{2}{|c|}{$\begin{array}{l}\text { Untuk Madd } \\
\text { dan Diftong }\end{array}$} \\
\hline ض & $=$ & $i=$ & $=\hat{a}$ (a panjang) \\
\hline$b$ & th & إين & $=\hat{\mathbf{i}}(\mathbf{i}$ panjang) \\
\hline ظ & $\mathbf{z h}$ & أوز & $=\hat{\mathbf{u}}$ (u panjang) \\
\hline$\varepsilon$ & $=$ & آوز & $=$ aw \\
\hline$\dot{\varepsilon}$ & $=\mathbf{g h}$ & = آين & $=$ ay \\
\hline
\end{tabular}




\section{ISI}

TRANSLITERASI

ARTIKEL

Mukhlis

Menimbang Kompatibelitas

Multikulturalisme dan Islam:

Ikhtiar Menggagas Pendidikan Islam

Multikultural di Indonesia • 201-224

Siti Muri'ah

Asesmen Akhlak Mulia:

Suatu Model Alternatif Penilaian

Pembelajaran Agama • 225-248

Yusuf Hanafi

Perkawinan Anak di Bawah Umur

dalam Perspektif Hukum Islam • 249-274

Arsyad Sobby Kesuma Menilai Ulang Gagasan Negara Khilâfah

Abû al-A'lâ al-Maudûdî • 275-300

Ahwan Mukarrom Al-A'immah min Quraisy:

Antara Doktrin dan Kebutuhan

Sosial • 301-322

Abd. Salam

Sistem Kalender Islam dalam Perspektif

Evolusi Syari'ah • 323-350

Bukhari

Desain Dakwah untuk Pembinaan

Keagamaan Komunitas

Elit Intelektual • 351-370

Ahmad Munir Teologi Properti:

Telaah Eksistensi dan Fungsi

Kekayaan • 371-392

BOOK REVIEW

Ahmad Fathan Aniq Discovering Indonesian Islam through Fatâwâ • 393-408

INDEKS 


\title{
TEOLOGI PROPERTI: \\ TELAAH EKSISTENSI DAN FUNGSI KEKAYAAN
}

\author{
Ahmad Munir*
}

\begin{abstract}
In the Al-Qur'an, human desire for wealth to meet their needs is viewed as common (thabii) and urgent (dlarûri). Wealth is considered a means for buman to be closer to their Creator. In theological perspective, human relation to their fellows and nature is fundamental. The relation is divided into three kinds. First, cooperative relation is the relation between buman and their fellows in which every human has the same right to use available natural resources. Second, consumptive relation is the relation between buman and nature in which buman is an authority for using natural resources and nature is an object. Third, responsible (mustakhlif) relation is the relation between human and their Creator in which human has to be responsible for using natural resources. Based on the relations, wealth for buman is expected to be a means of strengthening human characters and leading to the supreme state beside God and human.
\end{abstract}

Keywords: Pendidikan Islam, Multikulturalisme, Pluralitas, Keniscayaan Sosial-Budaya-Politik.

DALAM bahasa Arab, kekayaan diterjemahkan dengan kata almâl dan diulang sebanyak 86 kali dalam al-Qur’an. ${ }^{1}$ Jumlah

\footnotetext{
*Penulis adalah dosen Sekolah Tinggi Agama Islam Negeri (STAIN)

Ponorogo. email: ahmedmunir-stainpo@yahoo.com

${ }^{1}$ Kata-kata tersebut, ada yang berbentuk mufrad, jama', ma'rifah (definite), nakirah (indefinite), idlâfah (majemuk), maupun ghair idâfì. Muhammad Fuâd 'Abd al-Bâqî, Al-Mu'jam al-Mufahras li Alfâz̆h al-Qur'ân al-Karîm (Beirut: Dâr al-Fikr,1987), 682.
} 
penyebutan ini mengindikasikan bahwa kekayaan memiliki peran penting dalam kehidupan yang selalu diupayakan oleh manusia. ${ }^{2}$ Al-Qur'an menyodorkan pembahasan tentang kekayaan karena kekayaan memiliki fungsi yang erat dengan kehidupan. Al-Qur'an dalam membahas kekayaan, seimbang dengan membahas kepercayaan. Pengingkaran terhadap naluri manusia untuk memperoleh, memiliki, dan memanfaatkan kekayaan, sama halnya dengan mengingkari tabiat manusia itu sendiri. Tuhan telah memberi jaminan dan perlindungan naluri manusia dalam memperoleh, memiliki dan memanfaatkan kekayaan sekaligus mengecam orang yang mengingkari sekaligus menghalangi naluri tersebut (Qs. al-A'râf [7]:32). Naluri manusia terhadap kekayaan secara langsung berfungsi untuk mempertahankan kehidupan biologis. Adapun yang tidak langsung berfungsi untuk menegakkan kebenaran sebagai konsekuensi amanah yang telah diemban setelah mempertahankan kehidupan biologis. ${ }^{3}$

Kekayaan merupakan sarana untuk mencapai kesempurnaan hidup. Di dalamnya tercakup masalah kehidupan yang menjadi titik-tolak keberlangsungan dan kemaslahatannya, baik individu maupun kelompok. ${ }^{4}$ Al-Qur'an menganalogikan kekayaan sebagai perhiasan kehidupan (Qs. al-Kahfi [18]:46). Orang yang berupaya mendapatkan kekayaan, seyogyanya memperhatikan anjuran dan aturan al-Qur'an. Hal ini dimaksudkan agar tidak menimbulkan kerugian, baik bagi yang bersangkutan maupun orang lain serta kecemburuan karena kesenjangan antara kelompok kaya dengan kelompok miskin. ${ }^{5}$

2Syawqî 'Abduh al-Sâhî, Al-Mâl wa Thuruq Istitsmârih fî al-Islâm (Mesir: Mathba'ah Hissân, 1984), 18.

${ }^{3}$ Muhammad al-Bahî, Al-Fiker al-Islâmî wa al-Mujtama' al-Mu'âshir (Beirut: Dâr al-Kitâb al-Bannânî, 1975), 30.

4al-Sâhî, Al-Mâl ..., 11.

5Wahbah al-Zuhailî , Al-Qur'an dan Paradigma Peradaban, ter. Ahsani (Yogyakarta: Dinamika, 1996), 175. 
Kesenjangan hidup yang disebabkan oleh faktor kemiskinan, senantiasa mewarnai kehidupan manusia. Kesenjangan hidup tersebut menjadikan nasib orang miskin tergantung dan tergadaikan pada orang-orang kaya. ${ }^{6}$ Konsep dasar Islam yang fundamental secara makro tidak hanya terbatas pada aspek kepercayaan semata. Keimanan dan keyakinan tidak hanya menyangkut kepercayaan terhadap Tuhan saja, tetapi juga menyangkut pandangan dan sikap manusia terhadap sesama manusia dan juga alam raya. Wacana ini merupakan pandangan dasar teologi Islam itu sendiri.

\section{Kerangka Paradigmatik Teologis}

Al-Qur'an sebagai petunjuk bagi manusia, bukan hanya terbatas pada relasi Tuhan dengan manusia ('ubûdiyyah) semata, melainkan meliputi semua aspek kehidupan manusia; mulai dari eksistensinya sebagai individu hingga berkomunitas dengan berbagai relasi sosial dan kulturalnya. Dalam konteks ini, alQur'an lebih mengedepankan fungsinya sebagai pengatur keseimbangan dan keserasian, baik sesama manusia (mikrokosmos), sesama alam (makrokosmos), maupun terhadap Tuhan. Ketiga relasi ini merupakan prinsip dasar keyakinan yang fundamental, terbangun di atasnya pola, sikap, serta cara pandang manusia terhadap kehidupan. Prinsip ini ditanamkan pada diri manusia yang disebut 'aqîdah (teologi). ${ }^{7}$

Teologi adalah ilmu tentang Tuhan. Dalam kajian filsafat, teologi merupakan bagian dari metafisika yang menyelidiki masalah eksistensi menurut aspek dari prinsipnya yang terakhir, yaitu suatu prinsip yang luput dari persepsi inderawi. Objek dari prinsip tersebut adalah Tuhan dalam kaitannya dengan eksistensi, esensi, serta aktivitas-Nya. Teologi yang

${ }^{6}$ Marsel A. Boisard, Humanisme dalam Islam (Jakarta: Bulan Bintang, 1980), 70 .

${ }^{7}$ Seyyed Hossein Nasr, Intelektual Islam, Teologi, Filsafat dan Gnosis (Yogyakarta: CIIS Press, 1995), 12. 
pembahasannya didasarkan pada pernyataan-pernyataan wahyu, disebut teologi adikodrati atau teologi wahyu. Teologi ini bertugas menjelaskan bahwa wahyu merupakan fakta historis di satu pihak, dan berupaya menguraikan isi wahyu serta menjabarkan penyajian konseptual wahyu di lain pihak. ${ }^{8}$

Relasi manusia yang bersifat fundamental, baik terhadap Tuhan, alam maupun sesamanya, dapat dipetakan menjadi tiga tipe relasi. Pertama, relasi kooperatif (relationship) yaitu relasi manusia dengan sesamanya. Dalam relasi ini, manusia antara satu dengan yang lain berstatus sama dalam memanfaatkan potensi alam yang ada. Kedua, relasi konsumtif, yaitu relasi manusia dengan alam lingkungannya. Dalam relasi ini manusia berstatus penguasa dalam memanfaatkan alam, sementara alam sebagai objek kekuasaan manusia. Ketiga, relasi tanggung jawab (mustakhlif), yaitu relasi antara manusia dan Tuhan sebagai pertanggungjawaban dalam memanfaatkan alam. Relasi ini untuk menciptakan kemakmuran, agar alam dimanfaakan oleh manusia sesuai dengan kehendak penguasa tunggalnya (Allah).

Kekayaan dalam bahasa Arab disebut dengan kata mâl, yang berasal dari bentuk verbal $\left(f^{\prime}\right.$ ') mâla-yamîlu-mâylan, yang berarti mengumpulkan, condong, memiliki dan mempunyai. ${ }^{9}$ Dalam bahasa Indonesia, kekayaan didefinisikan sebagai barang atau sesuatu yang dapat dianggap sebagai kekayaan yang dapat dimiliki. ${ }^{10}$ Dengan demikian, kekayaan (al-mâl) dapat didefinisikan segala sesuatu yang menyenangkan manusia dan dipelihara, baik dalam bentuk materi maupun nilai atau manfaat. ${ }^{11}$

8Ibid.

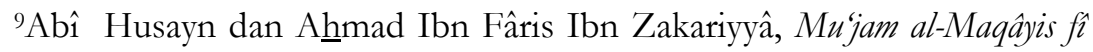
al-Lughah (Beirut: Dâr al-Fikr, 1994), 969.

${ }^{10}$ W.J.S. Poerwadarminta, Kamus Umum Bahasa Indonesia (Jakarta: Balai Pustaka, 1976), 347.

11'Abduh, Al-Mâl..., 54. 


\section{Pandangan al-Qur'an terhadap Kekayaan}

Al-Qur'an memandang kekayaan sebagaimana memandang kehidupan dunia secara integral, tidak secara apriori maupun berlebihan. Al-Qur'an memosisikan kekayaan sebagai sarana untuk meraih kesentosaan hidup manusia, bukan tujuan akhir hidupnya. Al-Qur'an kadang-kadang menyebut kekayaan dengan kebaikan (khayr) (al-Baqarah [2]:180) yang tergantung kepada sikap manusia dalam memfungsikannya, dengan keutamaan (fadl) (al-Jumû'ah [62]:4 dan 10), dan dengan kesenangan (matấ) (Qs. Âli 'Imrân [3]:14), karena jiwa manusia merasa senang ketika memiliki kekayaan. Al-Qur'an mengingatkan sikap manusia terhadap kekayaan bahwa kebaikan yang ada dalam kekayaan dapat menjadi penghalang manusia untuk mengingat Allah (Qs. al-Munâfiqûn [63]:9). Meskipun dalam kesempatan yang sama, kekayaan juga sebagai perantara bagi manusia untuk meraih pahala (Qs. al-Anfâl [8]:28).

Al-Qur'an mengakui bahwa kepemilikan kekayaan, didasarkan pada usaha manusia (al-kasb), pewarisan (al-irts), wasiat, dan hibah, sesuai dengan aturan yang dibenarkan oleh syara', di samping dengan cara-cara yang yang telah dianggap lazim dan legal. ${ }^{12}$ Namun di antara cara-cara untuk mendapatkan kekayaan tersebut, bekerja adalah salah satu cara yang paling mulia. Al-Qur'an menyeru manusia agar bekerja dan berkarya dalam kehidupan di samping menyembah Tuhan (Qs. alJumû'ah [63]: 10). Karena prestasi yang dicapai manusia hanya dapat diraih melalui berkarya atau bekerja. Bekerja dalam pandangan al-Qur'an tidak terbatas pada distribusi dan produksi, tetapi mencakup setiap usaha yang mengandung nilai atau manfaat yang menyebabkan timbulnya upah atau kepemilikan sesuatu. ${ }^{13}$

12al-Nashr, Al-Milkiyyah,... 20.

${ }^{136}$ Abduh, Al-Mâl...65. 
Bekerja merupakan salah satu sarana memperoleh kekayaan. Al-Qur'an memberikan rambu-rambu yang harus diperhatikan manusia dalam memperoleh, memiliki, dan memanfaatkan kekayaan. Di antara rambu-rambu tersebut adalah tidak boleh memakan kekayaan orang lain secara illegal (bâthil) (Qs. alBaqarah[2]:88), tidak boleh menggelapkan kekayaan anak yatim dan orang-orang lemah yang berada di bawah tanggungannya (Qs. al-Nisâ' [4]:2), harus menepati kesepakatan ('aqd) yang telah disepakati, tidak curang dalam timbangan dan takaran (Qs. alIsrâ' [17]:34-35), tidak boleh menempuh dengan cara riba, tidak boleh menyuap penguasa yang dapat menghalalkan yang haram dan mengharamkan yang halal (Qs. al-Baqarah [2]:278). ${ }^{14}$

Dalam pandangan al-Qur'an, kekayaan memiliki nilai ganda, nilai riil dan fungsional. Nilai riil kekayaan, Allah tidak menciptakan apa yang ada di alam ini secara sia-sia (Qs. alBaqarah [2]:26), sedangkan nilai fungsional, kekayaan dipergunakan untuk kemaslahatan manusia. Untuk mewujudkan nilai fungsional kekayaan, al-Qur'an menyeru dengan menggunakan redaksi yang bersifat persuasif, seperti mengajak memberi makan kepada kerabat, fakir miskin, dan orang-orang yang mengahajatkan (Qs. al-Insân [76]:8), mengajak mengeluarkan sebagian rejeki yang diberikan oleh Allah, memberi dan menyantuni orang yang meminta-minta (Qs. alBaqarah [2]:3). Akan tetapi, kadang-kadang al-Qur'an juga menyampaikannya dengan redaksi imperatif, seperti perintah untuk mengeluarkan zakat (Qs. al-Muzammil [73]:20), infâq (Qs. al-Baqarah [2]:267), memberi makan kepada orang yang kelaparan dan lain-lain.

Dalam sistem sosialis, individu tidak mendapat tempat untuk menguasai kekayaan. Segala bentuk kekayaan yang dapat digunakan oleh manusia pada umumnya dikuasai oleh negara. Penguasa dan segala perangkat aturannya selalu mengedepankan

\footnotetext{
14al-Bâhî, Al-Fikr ...47.
} 
buruk sangka terhadap hak individu. Sistem sosialis ini mengusung visi besar yang dijadikan tema sentralnya yaitu kesejahteraan umum. Sebelum kelompok sosialis merasakan hasil dari visi tersebut, secara tidak sadar mereka telah merasakan lebih dahulu penyiksaan dan perampasan hak individunya.

Dari persepsi dasar kedua kelompok tersebut, tampak bahwa persepsi al-Qur'an terhadap fungsi dan kepemilikan kekayaan bersinggungan dengan kedua kelompok tersebut. Dalam pandangan al-Qur'an, kepemilikan individu mendapatkan jaminan dan perlindungan penuh. Akan tetapi, terhadap barang yang dimiliki harus mencerminkan fungsi sosial yang selalu mengedepankan kemaslahatan sesuai dengan aturan syara'. AlQur'an memberi kesaksian tentang kecintaan manusia terhadap kekayaan (Qs. al-Fajr [89]:20).

Kecintaan manusia terhadap kekayaan yang berlebihan menyebabkan mereka bakhil dan dan melupakan pemilik kekayaan yang sesungguhnya. Sikap ini, sesungguhnya, dikecam keras oleh al-Qur'an (Qs. al-'Adiyât [100]:6-8). Al-Qur'an menawarkan solusi kepada manusia untuk menjembatani kesenjangan yang ada, yaitu dengan memberikan wadah penyaluran kekayaan sesuai dengan konteks penderma dan juga penyandang derma. Di antara wadah penyaluran kekayaan yang diungkapkan oleh al-Qur'an adalah infaq, zakat, sadaqah, dan lain-lain.

\section{Teologi Kekayaan Islam}

Konsep teologi dalam Islam, tidak lepas dari membicarakan hubungan antara Tuhan dan alam semesta yang di dalamnya juga hubungan Tuhan dengan manusia, Tuhan dengan alam, manusia dengan sesamanya, dan manusia dengan alam. Oleh karena itu, hubungan manusia dengan benda, baik dari aspek pandangan maupun sikap mendapat sorotan tajam dalam al-Qur'an, 
khususnya berkaitan dengan hubungan yang memerlukan kajian lebih jauh. ${ }^{15}$

Dalam pandangan al-Qur'an, hubungan antara manusia dan alam dapat dipetakan menjadi tiga sisi. Sisi pertama, alam semesta dan segala isinya milik Allah secara mutlak (Qs. al-Mầidah [5]:120). Kedua, alam semesta dan seluruh yang ada di dalamnya pemberian Allah kepada manusia yang harus difungsikan untuk kepentingan manusia dan makhluk lain (Qs. Luqmân [31]:20). Ketiga, manusia sebagai khalifah Allah, berhak mengurus dan memanfaatkan milik mutlak Allah dengan cara yang benar serta berhak memperoleh bagian dari hasil usahanya (Qs. al-Nisâ' [4]:32).

Dari pemetaan tersebut, dapat disederhanakan bahwa hubungan manusia dengan alam dan isinya dalam konteks pemilikan dan pemanfaatan adalah; (1) segala yang ada di alam adalah milik Allah secara mutlak; (2) manusia hanya diberi hak guna sebagai pengelola dalam batas-batas tertentu oleh Allah, bukan hak kepemilikan secara mutlak; (3) hak yang diberikan oleh Allah tersebut diimbali dengan kewajiban manusia mewujudkan kebaikan dan kemakmuran bersama; (4) Sebagai pengelola (mustakblif), dalam pengelolaan dan pemanfaatan milik mutlak Allah, manusia harus menyesuaikan kebijaksanaan dengan kehendak penguasa-Nya (Allah). ${ }^{16}$

Dengan demikian, kekayaan yang dimiliki manusia pada hakikatnya adalah hak mutlak bagi Allah (Qs. al-An'âm [6]:165). Akan tetapi, kepemilikan manusia terhadap kekayaan dibutuhkan kepastian aturan yang dapat memberi perlindungan dan jaminan dalam masyarakat. Hak milik seseorang diakui dan diberi perlindungan dengan dua pengertian: pertama, hak milik harus

15Djohan Effendi, "Konsep Teologi”, dalam Kontekstualisasi Doktrin Islam dalam Sejarah, ed. Budhy Munawar Rachman Jakarta: Paramadina, 1995), h.55.

${ }^{16} \mathrm{M}$. Daud Ali, Sistem Ekonomi Islam Zakat dan Wakaf (Jakarta: UI Press, 1988), 21 
diperoleh secara halal, dan kedua, hak milik harus berfungsi dan bernilai sosial. Pemilikan kekayaan merupakan titipan dan amanat yang harus ditunaikan manusia sesuai dengan pesan dan titipan pemberinya. Manusia bukan berarti tidak memiliki hak untuk memfungsikan kekayaan dalam hal-hal yang positif. Tindakan manusia terhadap kekayaan secara positif mendapat pujian dan balasan pahala dari Allah (Qs. al-Hadîd [57]:11). ${ }^{17}$

Dinamika manusia sebagai khalifah, didorong oleh dua keinginan dasar (gharîzah), yaitu keinginan untuk mengembangkan keturunan (al-tanassul), dan keinginan untuk memiliki dan mendapatkan kepuasan (al-tamalluk wa al-iqtinấ). Keinginan yang pertama untuk menjaga keberlangsungan jenis dan keturunan, sedangkan keinginan yang kedua untuk menjaga keberlangsungan hidup, baik individu maupun kelompok. Keinginan yang pertama mendorong manusia untuk menyambung hubungan dengan lain jenis, sedangkan keinginan kedua mendorong manusia berupaya untuk mencari, mendapatkan, mengembangkan, dan menyimpan kekayaan (Qs. Ali 'Imrân [3]:14).

Keinginan manusia untuk memiliki kekayaan, merupakan naluri dasar yang lahir bersama manusia. Keinginan tersebut menjadi dasar kreativitas dalam kehidupan. Al-Qur'an tidak bersikap depresif dan represif terhadap naluri manusia untuk memiliki kekayaan. Al-Qur'an hanya menempatkan naluri tersebut sesuai dengan ketentuan dengan menjelaskan cara memiliki yang benar dan cara memanfaatkan yang lazim (Qs. alFajr [89]:19-20). Kekayaan yang merupakan hak milik Allah secara mutlak, di dalamnya terdapat nilai sosial yang harus dijaga keberlangsungannya untuk kemaslahatan makhluk. ${ }^{18}$

${ }^{17}$ Anwar Haryono, Hukum Islam (Jakarta: Bulan Bintang, 1978),140.

${ }^{18}$ Dalam pandangan al-Qur'an, kepemilikan kekayaan dapat diperoleh dengan beberapa proses seperti; lewat usaha/bekerja, jual beli, jaminan kekayaan, mahar, khulu', wariasan, hibah, sadaqah, wasiat, waqaf, ghanimah, 
Al-Qur'an memandang bahwa kekayaan dilihat dari aspek perolehan, pemilikan serta pemanfaatannya, tidak lepas dari hubungan fundamental (teologi) antara manusia dan Tuhannya. Hubungan fundamental tersebut didasarkan pada sikap etis manusia dalam berinteraksi dengan kekayaan, mulai dari cara perolehan, pemilikan, dan pemanfaatan kekayaan.

\section{Fungsi Kekayaan}

Fungsi al-Qur'an sebagai petunjuk (هدا), keberadaannya dapat dirasakan oleh manusia melalui isyarat dari sebagian kandungan surat maupun ayat-ayatnya. Di dalam al-Qur'an, kata al-mâl (المال) yang disebut 87 kali, terdapat dalam 79 ayat dalam 38 surat. Dari jumlah pengulangan tersebut, 25 kali kata al-mâl dalam bentuk tunggal dan 62 kali dalam bentuk jamak. ${ }^{19}$ Secara konteks, kata tersebut dapat diklasifikasikan menjadi beberapa konteks;

Pertama, dinisbahkan kepada anak yatim (Qs. al-Isrâ’ [17]:34). Dalam konteks ini, al-Qur'an melarang orang menguasai kekayaan anak yatim, jika penguasaannya hanya menambah kesengsaraan bagi si yatim. Kalau penguasaan tersebut harus dilakukan oleh seseorang, harus disemangati tolong menolong atas kelemahan pemiliknya (si yatim). Kedua, yang dinisbahkan kepada Allah sebagai pemilik mutlak (Qs. al-Nûr [24]:33). Penyandaran kata al-mâl kepada Allah dalam konteks ini, untuk memberi penyadaran kepada orang kaya bahwa kekayaan dan apa saja yang berada di bawah kekuasaannya, adalah milik Allah yang harus diberikan sebagiannya kepada kelompok yang menghajatkan. Ketiga, sebagai objek kebajikan (ÇáĖÑ). Hubungan manusia dengan kekayaan bukan sekadar hubungan mutual (ketergantungan), khususnya yang berkaitan dengan

ibyâ al-mawât, luqathah, tebusan (diyat) pembunuhan dan lain-lain. Lihat, alNashr, Al-Milkiyyah ..., 20.

${ }^{19}$ al-Bâqî, Al-Mưjam,...682. 
pemenuhan kebutuhan fisik biologik, tetapi juga secara fungsional. Artinya, ikatan manusia dengan kekayaan bukan sekadar ketergantungan terhadap sesuatu, tetapi manusia mempunyai tanggung jawab keberlangsungan fungsi kekayaan (Qs. al-Baqarah [2]:177).

Konteks di atas menjelaskan bahwa kebajikan (ÇáĖ̃̃) yang dapat mengantarkan kedekatan manusia kepada Allah, bukan sekadar menghadapkan wajah dalam ibadah yang tanpa makna. ${ }^{20}$ Akan tetapi, kebajikan yang seharusnya mendapat perhatian adalah segala yang mengantar kepada kebahagiaan dunia dan akhirat seperti keimanan kepada Allah dan hari kemudian kepada Malaikat, Kitab suci, dan para Nabi.

Keempat, sesuatu yang dibanggakan. Kekayaan merupakan sesuatu yang dibanggakan oleh manusia dalam kehidupan. Karena kekayaan bersentuhan baik langsung maupun tidak langsung dengan kehidupan, al-Qur'an memandang orang yang membanggakan kekayaan sebagai orang yang sombong dan tidak terhormat (Qs. al-Kahfi [18]:34). Ketika Nabi Sulaiman didatangi utusan Ratu Balqis yang memamerkan bawaannya, Nabi Sulaiman menantang bahwa kekayaan yang mereka bawa itu tidak sebanding dengan apa yang telah diberikan oleh Allah kepadanya (Qs. al-Naml [27]:36). Kebanggaan manusia terhadap kekayaan, disejajarkan dengan kebanggaannya terhadap anak dan keturunan. Hal ini terjadi karena kekayaan yang diupayakan oleh manusia akan berakhir pada keturunan untuk melangsungkan regenerasi. Ketika manusia gagal mendapatkan kekayaan, ia tega membatalkan keturunannya dengan membunuh anaknya (al-Isrâ' [17]:31). Kelima, sebagai penyangga kehidupan. Isyarat al-Qur'an tentang kekayaan (ÇáãÇá), kadang-kadang mengaitkan kata tersebut dengan qatl/PẾa (pembunuhan) dan kadang-kadang dengan jihad (İą̧̇ï). Konteks pertama dapat dibaca dalam surah

${ }^{20}$ M. Quraish Shihab, Tafsir Al-Mishbâh, vol 1 (Ciputat: Lentera Hati, 2000), 364. 
al-Nisâ' [4]:29. Dalam konteks ini, perkawinan baik secara seremoni maupun ideologi membutuhkan kekayaan. Dalam seremoni, kekayaan digunakan untuk biaya perkawinan dan mahar, dalam ideologi kekayaan akan dijadikan penyangga kehidupan sebagai tanggung jawab terwujudnya keluarga bahagia (Qs. al-Baqarah [2]:195). Manusia telah menyadari urgensi kekayaan dalam kehidupan, dari kesadaran tersebut manusia kadang-kadang sering melampaui batas tata cara yang ditentukan dalam mencari.

Keenam, sebagai penyangga stabilitas sosial. Untuk menjaga stabilitas sosial, kekayaan memiliki peran penting. Dalam konteks ini, kata al-mâl di dalam al-Qur'an sering dikontekskan dengan kata jihad, sabilillah, dan kata anfus (Qs. al-Tawbah [9]:41). Dalam konteks ini, al-Qur'an memerintahkan muslim berjuang di jalan Allah. Dari redaksional ayat di atas, Allah seolah-olah memaksa muslim melakukan sesuatu yang memberatkan dan tidak menguntungkan bagi mereka. Oleh karena itu, al-Qur'an menegaskan bahwa perjuangan tersebut pada hakikatnya bukan untuk Allah dan Rasul-Nya. Perintah untuk berjuang pada hakikatnya adalah untuk kemaslahatan bagi yang diperintahkan. Kata jïhâd yang dikaitkan dengan kata anfus di samping kata amwâl pada ayat tersebut, menunjukkan upaya perjuangan manusia untuk melindungi hak dan kemerdekaannya secara totalitas. Kemerdekaan tersebut dari aspek nyawa, emosi, pengetahuan, tenaga, pikiran, bahkan waktu dan tempat. Karena itu, mujâhid adalah orang yang mempertahankan hak-hak di atas dengan mencurahkan seluruh kemampuannya dan bersedia berkorban apa yang ada pada dirinya untuk mempertahankan hak-hak tersebut. ${ }^{21}$

Kekayaan memiliki peran penting untuk menopang upaya manusia bertahan dalam kondisi kehidupan yang wajar. Kekayaan juga menjadi modal untuk menumbuhkan kekuatan

${ }^{21}$ Shihab, Tafsir,.. vol. II, 537. 
dalam penjagaan. Dalam konteks jïhâd, kata mâl dalam berbagai konteksnya selalu didahulukan dari kata anfus. Hal ini karena kekayaan dalam kondisi kritis sangat dibutuhkan keberadaannya. Oleh karena itu, fungsi sosial kekayaan tidak boleh dialihkan.

Ketujuh, sebagai ujian (fitnah). Di samping fungsi-fungsi di atas, al-Qur'an menyatakan bahwa kekayaan diposisikan sebagai fitnah (ujian/cobaan). Secara bahasa, kata fitnah berarti membakar emas di atas bara api agar nampak kemurniannya dari kandungan-kandungan lain. Kata tersebut kadang-kadang juga disinonimkan dengan kata balâ' agar manusia membentengi dirinya dari berbagai bentuk siksaan dan kesengsaraan (Qs. alAnbiyâ' [21]:35). ${ }^{22}$ Al-Qur'an menyebut dua hal yang dikategorikan sebagai fitnah. Pertama adalah kekayaan (amwâl), dan kedua adalah anak (aulâd) (Qs. al-Anfâl [8]:28).

Salah satu seruan Tuhan kepada orang yang beriman adalah untuk menunaikan amanat terhadap kekayaan dan anak (Qs. alAnfâl [8]:27). Kekayaan dan anak bisa jadi mengakibatkan seseorang enggan memenuhi seruan Tuhan karena takut miskin. Padahal kehidupan yang memenuhi seruan Tuhan adalah kehidupan yang mulia. ${ }^{23}$

Al-Qur'an mengobati sifat tamak, kikir, dan rakus manusia dengan mengingatkan bahwa kekayaan di samping berfungsi sebagai penyangga dan kelangsungan hidup, juga sebagai ujian dan cobaan bagi pemiliknya. Oleh karenanya manusia jangan sampai lemah dalam menghadapi ujian, dan jangan sampai mengabaikan tanggung jawabnya terhadap pemanfaatan kekayaan sesuai dengan fungsinya. Oleh karena itu, ayat di atas diawali dengan redaksi "ketahuilah" untuk menekankan kepada mitra bicara betapa penting apa yang akan disampaikan oleh ayat tersebut agar tidak diremehkan dan diabaikan. ${ }^{24}$

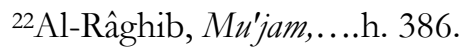

${ }^{23}$ Sayyid Quthub, Fî Drilâl,...., Juz II, 289.

${ }^{24}$ Shihab, Tafsir,...vol. 5, 425. 
Tanggung jawab terhadap kekayaan bukan sekedar menjalankan fungsi sosial kekayaan bagi orang lain yang membutuhkan, tetapi tidak kalah pentingnya agar kekayaan tersebut dipelihara dan dikembangkan dengan usaha yang baik sehingga menjadi berkembang. Dalam hal ini ujian terhadap kekayaan menyangkut pada proses bagaimana mendapatkan dan bagaimana membelanjakannya. Ujian terhadap kekayaan bukan sekadar dalam keadaan kekurangan, tetapi juga dalam kedaan kecukupan dan kelebihan. ${ }^{25}$

\section{Interpretasi Teologis terhadap Kekayaan}

Manusia memegang peran penting dalam kehidupan karena dunia sebagai sarana untuk menuju kehidupan yang abadi di hari akhir nanti. Kualitas kehidupan akhirat ditentukan oleh kualitas kehidupan manusia di dunia. Wajar jika orang mukmin dalam doanya selalu memohon dua kebahagiaan yang tak terpisahkan, yaitu kebahagiaan dunia dan kebahagiaan akhirat (Qs. al-Baqarah [2]:201). ${ }^{26}$

Islam adalah agama fitrah, kefitrahannya bukan sekedar mendasari romantisme hubungan antara pencipta (khâliq) dan yang dicipta (makhlûq). Romantisme sesama makhluk pun juga dilegalkan oleh al-Qur'an. Salah satu romantisme manusia dengan makhluk adalah naluri kecintaan manusia terhadap kekayaan dan kegemerlapan dunia (Qs. Âli 'Imrân [3]:14). Terhadap hal-hal tersebut, al-Qur'an memberikan dorongan positif di satu sisi, dan memberikan rambu serta ancaman di sisi lain jika naluri dianggap keluar dari pandangan dasar al-Qur'an.

Secara struktur biologis, manusia memiliki kesamaan dengan struktur makhluk hidup lainnya, khususnya yang berkaitan dengan pemenuhan hajat biologisnya. Pemenuhan hajat biologis

25'Itrîs, $M u^{\prime} j a m, . . .246$.

${ }^{26}$ Ahmad Syafi'i Maarif, Membumikan Islam (Yogyakarta: Pustaka Pelajar, 1995), 21. 
manusia dalam kehidupan, terpusat pada kekayaan. Oleh karena itu, salah satu fungsi kekayaan yang disebut oleh al-Qur'an adalah sebagai qiyâman ( قياما) atau sarana pokok kehidupan yang urgen, harus dijaga, dipertanggungjawabkan dan difungsikan dengan baik. Dari urgensi kekayaan atau kekayaan tersebut, alQur'an memerintahkan agar para wali mengambil alih tanggung jawab kepemilikan kekayaan atau kekayaan seseorang yang dinilai tidak mampu mengurus dan bertanggung jawab terhadap kekayaannya. Ketidakmampuan tersebut baik yang disebabkan oleh kelemahan jiwa, maupun keborosan dan kecerobohan tindakannya (Qs. al-Nisâ'[4]:5). ${ }^{27}$ Penangguhan atau pengalihan kekuasaan kekayaan kepada orang yang dipandang mampu dalam ayat di atas, didasarkan pada pertimbangan urgensi kekayaan sebagai tonggak dan sarana kehidupan orang banyak. Hal ini karena kekayaan bukan sekadar memberikan fungsi kepada penguasanya, tetapi fungsinya diperuntukkan bagi semua makhluk. ${ }^{28}$

Pandangan al-Qur'an terhadap kekayaan sangat positif, sehingga kekayaan kadang-kadang disebut sebagai "kelebihan atau keutamaan" ( الفضل yang harus diperebutkan manusia setelah ia menunaikan kewajiban terhadap Tuhannya (Qs. alJumû'ah [62]:10).

Sesuatu dianggap urgen, apabila memiliki daya tarik secara khusus. Perhatian terhadap sesuatu biasanya disebabkan oleh fungsi dan nilai gunanya. Dalam surat al-Nisâ' [4]:5 dijelaskan, bahwa fungsi kekayaan yang fundamental adalah sebagai sarana pokok kehidupan. Dari pola struktur di atas, kata mâl dengan berbagai bentuknya dapat diklasifikasikan; pertama, dilihat dari kuantitas bentuknya, bentuk jamak (امو ال ) lebih banyak disebut dari bentuk tunggal (مال Hal ini mengisyaratkan bahwa

${ }^{27}$ M. Quraish Shihab, Wawasan al-Qur'ân (Bandung: Mizan, 1996), 404.

${ }^{28}$ Rasyîd Ridlâ, Tafsîr al-Qur'ân al-Hakîm, Jilid II (Beirut: Dâr al-Fikr, t.t.), 122. 
permasalahan kekayaan lebih banyak menyangkut masalah sosial, baik dari segi proses pengumpulan maupun dari segi fungsi dan manfaatnya; kedua, dilihat dari segi penisbahan pemiliknya, kata tersebut lebih banyak dinisbahkan kepada kata ganti (dlamîr) yang menunjuk pada kelompok sosial, atau manusia secara umum dan kelompok lemah seperti anak yatim. Kata tersebut hanya satu kali dinisbahkan kepada pribadi (i) yang menunjukkan penyesalan pemiliknya (Qs. al-Hâqqah [69]:28). Penisbahan kata mâl/amwâl kepada pemilik tersebut mengisyarakan bahwa kekayaan akan berkembang dan lebih berperan sesuai dengan fungsinya jika beredar di kalangan orang banyak. Kekayaan akan memberikan fungsi, berkah, dan mencukupi hajat hidup, khususnya kelompok lemah. Mereka itu sebenarnya yang paling butuh terhadap kekayaan, atau dalam kelompok itulah kekayaan akan berkembang dan berperan secara optimal; ketiga, jika kata mâl/amwâl tampil secara mandiri, menunjukkan bahwa kekayaan pada hakikatnya adalah bukan di bawah kekuasaan seseorang. Secara hakiki, kekayaan adalah milik Tuhan sebagai jaminan kehidupan manusia. Atau bisa jadi karena di alam ini ada sesuatu yang gunanya belum diketahui oleh manusia, sehingga sementara waktu manusia tidak menganggapnya sebagai kekayaan. ${ }^{29}$

Kesadaran manusia terhadap agama tidak seluruhnya positif. Anggapan terhadap agama sebagai pembatas kebebasan, baik untuk melakukan sesuatu maupun untuk meninggalkannya, sering terbesit dalam diri manusia. Al-Qur'an memandang bahwa esensi petunjuk agama adalah untuk memandang dan mengungkap fenomena yang melingkupi kehidupan manusia melalui tanda-tanda Allah di alam. Tanda-tanda tersebut ada yang berbentuk qawliyyah, maupun berbentuk kawiyyah. ${ }^{30}$

\section{${ }^{29}$ Shihab, Wawasan ..., 406.}

${ }^{30}$ Muhammad al-Ghazali, Berdialog dengan al-Qur'an (Bandung: Mizan, 1996), 15. 
Salah satu dari kecenderungan dasar manusia adalah keinginannya untuk mengaktualkan diri melalui pengembangan keturunan (al-tanassul) dan kepemilikan melalui pencarian kecukupan (al-iqtinấ). Melalui kedua upaya ini, manusia berjuang untuk mempertahankan sekaligus menjaga kelangsungan jenis dan keturunannya. Dalam menjaga keberlangsungan tersebut, manusia dihadapkan pada dua sisi, yaitu sisi positif dan negatif. Potensi yang ada pada diri manusia hendaknya dapat difungsikan untuk melihat sisi positif yang harus diprioritaskan sehingga ia tidak tergoda oleh keglamoran eksoterik serta tidak tertutup pandangannya terhadap esoterik yang ada di balik eksoterik.

Manusia yang mampu memandang wilayah esoterik dalam hidupnya, al-Qur'an mengategorikan mereka itu sebagai kelompok kanan (maimanah). Sementara mereka yang hanya mampu menembus tataran eksoterik, al-Qur'an mengategorikan dalam kelompok kiri (masy'amah) (Qs. al-Balad [90]:18-19).

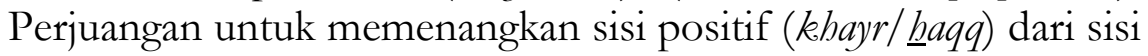
negatif (syarr/bâthic) dalam kehidupan, mendapat dukungan moral dari al-Qur'an. Manusia dituntut serius untuk mencari hikmah dan kebaikannya. Secara moril, Tuhan telah menjanjikan dukungan-Nya kepada manusia, bahwa Dia akan memenangkan yang haqq dan akan menyirnakan yang bâthil (Qs. al-Anbiyâ' [21]:18-19). ${ }^{31}$

Meskipun manusia bergelut dengan materi dan kekayaan, tetapi kehidupan manusia bukan sekadar tertuju pada pengembangan keturunan dan kekayaan. Kekayaan dan keturunan untuk menopang perjuangan (kifâh) dalam meraih dan menegakkan nilai dan kemuliaan. Di sini dan dalam posisi ini, kekayaan berfungsi positif dan urgen. Sedang dunia hanya menjadi panggung bagi manusia untuk berjuang dalam meraih kemenangan.

31al-Bahî, Al-Fikr,... 22. 
Ketika al-Qur'an menyebut kehidupan yang berkaitan dengan kekayaan dengan nada negatif (Qs. al-Anfâl [8]:28), pandangan tersebut sebenarnya bukan ditujukan dan diarahkan kepada kekayaan. Akan tetapi, diarahkan pada sikap manusia terhadap kekayaan, agar manusia tidak lupa terhadap fungsi dan nilai kekayaan serta lengah terhadap tugas utamanya dalam kehidupan. Dalam kondisi-kondisi tertentu, al-Qur'an mengabstraksikan kekayaan dengan kondisi yang riil, baik dari aspek manusia maupun dari aspek materinya.

Kekayaan dalam pandangan al-Qur'an adalah positif dari aspek manapun. Secara ontologis, alam juga makhluk Tuhan yang memiliki derajat dan posisi kemakhlukan yang sama dengan manusia. Jika manusia diberi predikat kemuliaan karena mampu memfungsikan alam dan isinya untuk sesuatu yang positif, maka alam diberi predikat itu karena telah tunduk (musakh-khar) untuk memenuhi hajat hidup manusia. Dalam kondisi ini, alam lebih awal tunduk (muslim), baik kepada Tuhan maupun kepada manusia, dari pada manusia yang menggunakan alam. Jika manusia dituntut tunduk hanya kepada Tuhan semata, maka alam dituntut tunduk kepada Tuhan dan manusia sebagai khalifah Tuhan di muka bumi. ${ }^{32}$

Islam sebagai agama fitrah, meletakkan pandangan terhadap kekayaan atau materi secara proporsional. 33 Ketika manusia berposisi sebagai makhluk biologis, al-Qur'an melegalkan keharusan manusia untuk mencari materi atau kekayaan dalam rangka memenuhi kebutuhan hidupnya (Qs. al-Qashâsh [28]:77). Pada waktu yang bersamaan al-Qur'an menajamkan pandangan manusia bahwa kekayaan bukanlah segala-galanya yang harus dikejar (Qs. al-Tawbah [9]:38).

${ }^{32}$ Safwan Idris, Gerakan Zakat dalam Pemberdayaan Ekonomi Ummat: Pendekatan Transformatif (Jakarta, Citra Putra Bangsa, 1997), 189.

${ }^{33}$ Masdar F. Mas'udi, "Hak Milik Dan Ketimpangan Sosial, Telaah Sejarah dan Kerasulan", dalam Kontekstualisasi Doktrin Islam dalam Sejarah, ed. Budhy Munawar Rachman (Jakarta: Paramadina, 1995), 643. 
Al-Qur'an mengecam keras dan menganggap tindakan manusia sebagai kebodohan bagi mereka yang mengorientasikan kehidupannya hanya untuk dunia. Orientasi tersebut hanya akan membuka jurang permusuhan yang diakibatkan oleh persaingan yang tidak mengindahkan nilai-nilai kemanusiaan. ${ }^{34}$ Al-Qur'an mewajibkan manusia untuk memenuhi kebutuhannya secara wajar dan normal (Qs. al-Isrâ' [17]:29). Al-Qur'an akan mengecam manusia yang memenuhi kebutuhan hidupnya melebihi batas-batas yang ditentukan. Pelampauan batas tersebut adakalanya disebabkan karena menahan kekayaan, maupun karena menghabiskan kekayaan secara berhamburan, terlebih merampas hak orang lain dengan cara yang tidak dibenarkan. Kebutuhan hidup harus dipenuhi, tetapi pemenuhannya tidak selalu identik sikap boros dan foya-foya (Qs. al-Furqân [25]:67).

Dari sudut esoterik (spiritualitas), al-Qur'an berpesan kepada manusia agar mengambil jarak terhadap ketiga nafsu tersebut. Dalam konteks ini, orang suci bukanlah mereka yang tidak bergaul dan bergumul dengan dunia materi, akan tetapi mereka yang mampu mengambil jarak dan menahan diri agar tidak terseret ke dalam tiga jebakan nafsu tersebut (tazyinn, isrâf dan tabdzir). Pandangan al-Qur'an terhadap dunia materi atau kekayaan adalah terbuka. Al-Qur'an menghargai apresiasi serta naluri manusia terhadap materi. Ketertarikan manusia dengan materi dan keindahan kehidupan, adalah keniscayaan yang tidak boleh diingkari oleh manusia. Dalam hal ini, al-Qur'an melegalkan naluri tersebut selama tidak melampaui yang dilarang, dan mengecam bagi mereka yang mengingkarinya (Qs. al-A'râf [7]:32).

Jika dipersepsikan bahwa si fakir dengan kefakirannya dapat berpeluang untuk kufur, maka dalam waktu yang sama juga harus diakui bahwa orang kaya dengan kekayaannya lebih berpeluang untuk hal itu. Kalau kekufuran si fakir hanya

${ }^{34}$ Effendi, Konsep, ....57. 
menimpa dirinya, sementara kekufuran si kaya lebih berpeluang untuk mengkufurkan dirinya dan orang lain. Orang fakir ditindas dengan kekayaan orang kaya sehingga mereka menjadi tidak berdaya. Akhirnya si fakir juga ikut kufur akibat kefakirannya. Perlu digaris bawahi bahwa kecaman dan pujian terhadap kedua kondisi tersebut, baik fakir maupun kaya bukan masalah kefakiran dan kekayaan. Akan tetapi, kecaman dan pujian tersebut berkaitan dengan sikap manusia terhadap kekayaan yang terefleksikan dalam kedua kondisi tersebut.

\section{Catatan Akhir}

Teologi sebagai patron untuk melihat kualitas keberagamaan yang membentuk tingkah laku manusia. Teologi sering dipahami secara sepihak, yaitu hubungan fundamental antara manusia dan Tuhan. Akibatnya, manusia dalam merespon kehidupan sering bersikap statis, apatis, pesimis, dan pasrah. Keyakinan terhadap Tuhan, harus direfleksikan dalam berhubungan dengan sesama makhluk. Konsep ini dapat menyadarkan posisi diri manusia yang berada antara aspek ruh dan materi.

Al-Qur'an memandang kekayaan secara positif. Olah tingkah manusia yang membuat image kekayaan negatif. Penyebutan alQur'an terhadap kekayaan yang dirasa kurang merestui, bukan ditujukan kepada materinya, tetapi pada sikap manusia terhadap kekayaan yang menodai citra kesuciannya. Pitutur al-Qur'an dalam berinteraksi dengan kekayaan, bukan masalah teknis dan strategis, melainkan berkaitan dengan etika manusia dalam memandang eksistensi dan fungsi kekayaan sebagai refleksi nilainilai moral yang terbangun dalam teologi yang diyakini.

Kemuliaan dan kehinaan manusia bukan ditentukan kekayaan, melainkan sikap dalam berinteraksi dengan kekayaan. Orang kaya yang serakah yang mengganggu orang lain menjadi kaya, dan orang miskin yang malas yang hanya mengganggu kekayaan orang kaya, keduanya dikecam oleh al-Qur'an. 


\section{Daftar Pustaka}

Abî Husayn dan Ahmad Ibn Fâris Ibn Zakariyyâ, Mưjam alMaqâyis fî̀ al-Lughah (Beirut: Dâr al-Fikr, 1994).

Agus Purwadi, Teologi Filsafat dan Sains (Malang: UMM Press, 2002).

Ahmad Syafici Maarif, Membumikan Islam (Yogyakarta: Pustaka Pelajar, 1995).

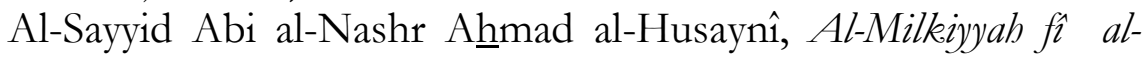
Islâm (Kairo: Dâr al-Kutub al-Hadîtsah,1952).

Anwar Haryono, Hukum Islam (Jakarta: Bulan Bintang, 1978).

Djohan Effendi, "Konsep Teologi", dalam Kontekstualisasi Doktrin Islam dalam Sejarah, ed. Budhy Munawar Rachman (Jakarta: Paramadina, 1995).

M. Daud Ali, Sistem Ekonomi Islam Zakat dan Wakaf (Jakarta: UI Press, 1988).

M. Quraish Shihab, Tafsir Al-Mishbâh, vol 1 (Ciputat: Lentera Hati, 2000).

M. Quraish Shihab, Wawasan al-Qur'ân (Bandung: Mizan, 1996).

Marsel A. Boisard, Humanisme dalam Islam (Jakarta: Bulan Bintang, 1980).

Masdar F. Mas'udi, "Hak Milik Dan Ketimpangan Sosial, Telaah Sejarah dan Kerasulan", dalam Kontekstualisasi Doktrin Islam dalam Sejarah, ed. Budhy Munawar Rachman (Jakarta: Paramadina, 1995).

Muhammad al-Bahî, Al-Fiker al-Islâmî wa al-Mujtama' al-Mu'âshir, (Beirut: Dâr al-Kitâb al-Bannânî , 1975).

Muhammad al-Ghazali, Berdialog dengan al-Qur'an (Bandung: Mizan, 1996).

Muhammad Fuâd 'Abd al-Bâqî, Al-Mu'jam al-Mufahras li Alfâz̧h al-Qur'ân al-Karim (Beirut: Dâr al-Fikr,1987).

Rasyîd Ridlâ, Tafsîr al-Qur'ân al-Hakîm, Jilid II (Beirut: Dâr alFikr, t.t.). 
Safwan Idris, Gerakan Zakat dalam Pemberdayaan Ekonomi Ummat: Pendekatan Transformatif (Jakarta, Citra Putra Bangsa, 1997), 189.

Seyyed Hossein Nasr, Intelektual Islam, Teologi, Filsafat dan Gnosis (Yogyakarta: CIIS Press, 1995).

Syawqî 'Abduh al-Sâhî, Al-Mâl wa Thuruq Istitsmârih fì al-Islâm (Mesir: Mathba'ah Hissân, 1984).

W.J.S. Poerwadarminta, Kamus Umum Bahasa Indonesia (Jakarta: Balai Pustaka, 1976)

Wahbah al-Zuhailî, Al-Qur'an dan Paradigma Peradaban, ter. Ahsani, (Yogyakarta: Dinamika, 1996), 175. 